\title{
Anti-crisis Measures for Improving the Functioning of Commercial Bank
}

\author{
Tatiana Bondarenko \\ Plekhanov Russian University of Economics \\ Moscow, Russia \\ E-mail: t.g.bondarenko@gmail.com
}

\author{
Olga Zhdanova \\ Plekhanov Russian University of Economics \\ Moscow, Russia \\ E-mail: olga.angel@bk.ru
}

\begin{abstract}
The article specifies that the process of anti-crisis management in a commercial bank should be an integral part of the accounting, customer, interest and credit policies of the bank, containing strategic directions of banking activities in the field of its active and passive operations, especially determining the degree of risk, its compliance with bank financial possibilities, assessment, analysis and identification, etc. The authors proposed anti-crisis measures to be used by any commercial bank for further solvency recovery program as conducting stress testing in credit transactions, as well as within bank's liquidity management. These measures may help to reduce the credit risk of the bank, as the most frequent, and can be used in risk management both in crisis situations and on a permanent preventive basis.
\end{abstract}

Keywords-commercial bank; risk; stress testing; anti-crisis management; liquidity risk; credit risk

\section{INTRODUCTION}

Topic Relevance: banking is an important aspect of the economy around the world and in Russia, in particular. Banks consolidate funds of both legal entities and individuals. The range of banking operations covers almost the entire financial system of the country. This topic is of particular importance in Russian economy against the background of fragile situation in the country's economy and large losses observed in the financial sector and subsequent intervention of governments and central banks. A significant number of banks are not able to comply with regulatory requirements on equity adequacy, resulting in deprivation of such organizations of licenses to conduct banking activities. Closure of credit institution causes significant problems for financial system.

Statistical data, analytical reviews and methodological materials of various analytical agencies were the information and statistical base of the study, as well as regulatory documents of the Russian Federation and economic-oriented articles in Internet publications, materials of international and all-Russian scientific and practical conferences were examined.

Working method and methodology: in the course of study, the following methods were used: analysis and synthesis, deduction and induction, system and comparative analysis, classification and grouping, and a number of other scientific methods.

\section{ORGANIZATION OF EMPIRICAL OBSERVATION OF ANTI-CRISIS MANAGEMENT CONCEPT}

Modern concept of this term is interpreted as follows: "Anti-crisis management is coordinated actions aimed at preventing the crisis situation, easing the intensity of crisis and eliminating its negative consequences" [1].

There are two approaches - emergency and routine preventive - on the basis of which it is possible to define the concept of anti-crisis management in a broad and narrow sense. For example, E. A. Tatarnikov in his work defines this concept as follows: "Anti-crisis management in a broad sense is a system of management measures for diagnosis, prevention, neutralization and overcome of crisis phenomena and their causes at all levels of economy (micro-, mesomacro-, world levels). In other words, it is a system management of a particular business entity at a particular level of economy in terms of crisis counteraction. In a narrow sense, anti-crisis management is a system of organizational and management measures in respect of individual enterprise in crisis, that is usually expressed in insolvency, which, in the event of protracted irresistible nature, is neutralized through bankruptcy" [2].

As a result, it can be concluded that anti-crisis management is the forecast of potential crises in economic and financial spheres of organization, prevention of those crises that have been analyzed, overcome of crisis situations that could not be prevented, and elimination of consequences after the crisis occurred with the plan development to prevent crisis in the future.

That is, anti-crisis management is one of directions of bank management, both tactical and strategic, which includes a set of measures aimed at anticipating crisis in a commercial bank, preventing or overcoming it, as well as analysis of obtained results for introduction of necessary adjustments to the credit institution activities.

\section{THE FORMING EXPERIMENT "FACTORS FOR}

DEVELOPMENT OF CRISIS CONDITION IN A COMMERCIAL BANK"

In the course of its activities, the bank is influenced by factors just from both internal and external environment. Without exception, all factors have every chance to be both 
favorable and negative. The difficult influence of negative factors of the internal and external environment generates a banking crisis.

Negative factors have a negative impact on bank's activities and are implemented in the form of risks. The risk is a threat of loss of numerous sources, non-receipt of income, occurrence of unforeseen expenses due to financial transactions. For this reason, the bank's anti-crisis management initially begins with the development of measures to regulate emerging banking risks.

We consider the effect of these factors using the example of the Russian banking sector. Reduction in margins and stagnation of corporate lending encouraged banks to increase credits in more profitable retail. However, the lack of prerequisites for increase in borrowers' solvency in the aging of 2017-2018 issues is very likely to lead to crisis over the next two years. Anticipating the segment overheating, the Bank of Russia took measures to cool lending to the population, but this would only partially diffuse the effect of deterioration in the quality of retail portfolios. Increased competition for first-class corporate borrowers will also have a negative impact on profits in the segment of bank guarantees, which, in terms of expected M\&A transactions, will lead to further increase in market concentration on major players.

The retail boom will be replaced with crisis over the next two years. For the period from 01.07.2017 to 01.07.2018 the size of individuals' debt to banks increased by $19 \%$, the segment dynamics reached a peak from 2014. At the same time, real disposable household income was stagnated during this period. In addition, the negative impact on population solvency would further increase VAT and fuel prices, as well as depreciation of ruble, resulting in increase in default in 2019-2020 retail segment. For the past two years, the corporate lending segment showed negative or weak growth rates. Stagnation in economy will not allow the volumes of corporate lending to grow without taking into account currency revaluation by more than $3 \%$ during the 2 nd half of 2018 and 2019, and activation in this segment of large banks undergoing the rehabilitation procedure with state participation will lead to further strengthening of competition for first-class borrowers. As a result, the interest margin level will continue to decline. Sector consolidation will be accompanied by the activity of large and medium-sized banks in terms of M\&A transactions. The lack of growth points will lead to continuation of the process of washing out inefficient players from the market. In turn, stable middleclass and highly specialized banks are increasingly likely to become candidates for takeover by banks of the federal level. In addition, within the framework of cost optimization programs, a clearly noticeable trend will continue to consolidate banks that form banking groups on the basis of single license (the largest of merger transactions, which are known from public sources, are shown in the table). Large banks will use the opportunity to deepen business diversification by purchasing loan portfolios from banks that are experiencing difficulties or are planning to reduce their presence in the Russian banking market [3].
Where the crises of separate financial units have occurred, there is a need to take such anti-crisis measures that will permit the crisis to go beyond the bank and become the system ones [4].

Thus, at present the banking system may be said to exist in a very tough struggle. The number and nature of crises, faced by the banking system of the Russian Federation, demanded both development and tightening of regulations on the part of legislation, and the requirements to commercial banks themselves, which form their individual crisis management programs. Risk identification and reduction or minimization of their negative impact, assets quality increase, alignment of liabilities settling level in the accounts with credit organizations have become the tasks for such plans.

\section{Discussion}

Risk management plays an important role in any commercial bank operations. The Bank's risk management policy in the conditions of anti-crisis management should be aimed at formation of integrated risk management system, adequate to the nature and scope of bank operation, the profile of risks accepted by it, and meeting the needs of further business development.

By estimations of "Expert RA" [3], by 2018, in the previous three years the volume of non-core assets on banks' balance sheets increased by more than twofold and amounted to 2.3 trillion rubles. It is about $3 \%$ of the total assets of Russian banks. About $2 / 3$ of such assets are investments in shares and other equity participation, $19 \%$ are assets in trust management and investments in shares, the remaining $14 \%$ are direct investments in real estate and other non-current assets. More than half of increase in non-core assets in 2017 (284 of 580 billion rubles) provided banks mainly at the expense of funds contributed to the authorized capital of other organizations.

The main reasons for emergence of non-core assets are withdrawal from troubled borrowers, owners' assistance and investments in the capital of "subsidiaries" working in other sectors. The first two reasons relate to 2015-2017 economic downturn: both the volume of troubled loans and the need for compensation of losses incurred due to the crisis through assistance of shareholders are growing during the crisis. The observed increasing investments in capitals of non-bank companies may be associated with both tightening of bank regulation (so-called "regulatory arbitrage"), and with the general decline in attractiveness of investments in banks: due to these investments, capital flows into more interesting segments.

In 2018, we will probably see the peak values of the share of non-core assets, and then it will decline. Non-core investments often appear on the balance sheets of banks, in other times than the crisis years, but within 1.5-2 years after reaching the lowest point of economic recession. In general, banks are reluctant to recognize non-core assets on their balance sheets, so the inflow of such assets on the balance sheet weakens, while the growth of economic activity gives banks more chances to sell previously received assets. 
Now banks are actively working on the sale of non-core assets, and many managed to reduce the size of such investments on the balance sheet in 2017. Although non-core assets are easier to turn into money than bad loans, their abundance on the balance sheet distracts the bank's capital and prevents the issuance of new loans.

According to the authors of the article, in order to prevent the implementation of significant risks in the development of stress scenarios in the activities of credit institution, it is necessary to implement the following recommendations:

- In terms of corporate credit risks, to develop a Credit Policy that establishes priority directions and principles of lending corporate and retail borrowers and regulates the competence of Bank's management bodies in making credit decisions;

- In terms of retail credit risks, to approve risk indicators and decision-making strategies for retail products;

- In terms of operational risks, to approve the strategy of debt collection for individuals;

- In terms of treasury operations, to develop and approve the investment declarations of securities portfolios and conversion operations;

- In terms of managing the assets structure and liabilities of the Bank, to approve the Committee on asset and liability management of the Bank;

- In terms of country risk, to introduce restrictions on transactions with foreign borrowers and counterparties operating in the territory of states characterized by unstable financial and economic conditions;

- In terms of stock market risk, to set limits on issuers, restrictions on possible negative revaluation (VAR);

- In terms of liquidity risk, to forecast cash flows, maintain a sufficient level of highly liquid assets in order to hedge liquidity risk;

- In terms of regulatory risk, to agree on internal regulatory documents of the Bank, including through performing control checks.

Let us consider in more detail some recommendations to minimize risks that, according to authors, have the most negative impact on any commercial bank activities as a whole and its individual financial results in particular. First of all, the bank needs to control the level of all risks. It is most expedient to carry out such control by means of structural scheme of the management process by means of present types of risks, which allows increasing the bank financial stability, on the one hand, by minimizing possible losses, and, on the other hand, by obtaining implicit income from operations with a reduced level of their non-conduct [5].

As part of credit risk minimization, it is also necessary to consider the issue of improving the borrower's database, the implementation of which should be appropriately carried out in the following areas:

- development and practical use of system of indicators characterizing the bank's work to meet the needs of borrowers;

- segmentation of borrowers by levels of interest rates on credit products used by them and their profitability;

- modeling of borrowers "profile" by different characteristics (creditworthiness and solvency, loan security, etc.)

- conducting credit risk stress testing.

Credit risk factors can be used to compose stress tests simultaneously or separately. Stress testing method in a commercial bank usually involves:

- methodology for building stress testing of both onefactor and multi-factor risks;

- procedure for setting stress loss limits and defining powers to set such limits;

- limit monitoring process in terms of stress losses.

However, most credit instruments are not traded on the market, so there is very little information about specified value of particular instrument. Default on credit instruments is also infrequent event, and defaults occurred are tracked and recorded less effectively than, for example, changes in market prices.

In this regard, it is advisable to note general current trends:

- increase in impact on bank's liquidity of off-balance sheet financial instruments (assets and liabilities are more likely managed by Russian commercial banks through interest rate and currency derivatives);

- increase in a share of wholesale funding instruments in bank liabilities compared to retail (this is primarily due to receipt of loans from the Central Bank of the Russian Federation and bonds issue);

- increasing influence of market factors on bank funding opportunities;

- complication of bank credit operations (floating interest rate regimes, built-in financial instrumentsoptions, etc.).

Thus, observing transformations occurring in the banking sector, we can conclude: due to globalization of international financial markets, complexity of banking transactions and operating environment, the liquidity of Russian banks is increasingly dependent on uncertain market factors such as interest rates, credit spreads and other market indicators. Even a slight change in their magnitude or volatility may result in significant additional liabilities for the bank.

It is logical to assume that the methods traditionally used by banks to manage liquidity risk (GAP analysis of payment position or, for example, maintaining liquid assets stock) 
may not be effective in the current circumstances. The commercial bank is not reliably aware of future gaps (deficiency) in liquidity, and investing a large share of assets in liquid instruments is economically unprofitable and does not guarantee full protection against liquidity risk.

Let us consider in more detail the impact of the above types of liquidity on commercial bank operation. In accordance with the above definition, the amount of expected liquidity is influenced by a number of factors: interest rates, cross-exchange rates, scope of price fluctuations on market financial instruments (spreads), correlation between the factors of financial markets, volatility of factors. However, the last two factors, correlation and volatility, are of the greatest interest. Correlation is important due to existing difficulties in predicting its change in the future, and volatility - due to complex nonlinear structure of distribution of its values (volatility surface), as well as the complexity of its objective predictive assessment in low liquidity conditions of the ruble derivatives market. Both these factors, in the presence of a significant share of expected liquidity in the total liquidity of the bank, bear the greatest risks for commercial bank.

The basic principles of stress testing of expected liquidity. When stress testing the bank's expected liquidity, it is advisable to observe the following principles:

- stress testing should take into account both short-term and long-term changes in risk factors (1-30-day changes in factors are usually used, although liquidity problems have led to banks insolvency within both several days and years);

- stress testing should not be mixed (for example, decrease in expected liquidity due to minor and significant changes in the financial market factor is the same scenario with different stress levels);

- stress testing should be absolutely relevant (appropriate) to the specifics of the bank under test (for example, the expected bank liquidity, operating in financial markets of particular state, should be tested taking into account changes in the financial market factors of that particular country).

If maintenance of highly liquid assets stock is considered as the main way to reduce the risk of short-term liquidity deficit under stress, it can be reliably argued that no bank can avoid this risk. No commercial bank will be able to hold highly liquid assets (standby liquidity) in size sufficient to ensure survival in the event of significant one-time liquidity deficit. At the same time, the indicator of longest possible period of bank activities in crisis is, as a rule, transparent and intuitive to the participants of the strategic decision-making process in the bank.

Separately, it should be emphasized that sharp falls in the value of assets and collateral directly affect the events of market risk, followed by the aggravation of problem of liquidity crisis development.

We also emphasize that the practice of stress testing shows that only some tests and activities should be carried out regularly, for example, they may include portfolio restructuring, sale of positions or portfolios, hedging, etc.

\section{CONCLUSION}

Anti-crisis management is a whole complex of interrelated measures from early crisis diagnosis to measures of its overcome. Nature of crises, faced by the banking system of the Russian Federation, demanded both development and tightening of regulations on the part of legislation, and the requirements to commercial banks themselves, which form their individual crisis management programs. Risk identification and reduction or minimization of their negative impact, assets quality increase, alignment of liabilities settling level in the accounts with credit organizations have become the tasks for such plans.

Summarizing the whole direction of bank's work during the crisis period, we note that the purpose of anti-crisis management in commercial banks is to determine the susceptibility of bank's financial condition to unfavorable improbable but significant change in financial market factors. With regard to the topic of the article, the tasks of anti-crisis management can be defined as follows:

- assessment of maximum outflow of funds of commercial bank as a result of unfavorable improbable change in financial market factors;

- assessment of maximum possible period of bank operating activities in the conditions of unfavorable improbable and long-term change in financial market factors.

\section{REFERENCES}

[1] NATO Logistics Handbook. Definitions.- [Electronic resource] URL: http://www.nato.int/docu/logi-en/1997/defini.htm.

[2] E. A. Tatarnikov Anti-Crisis Management. Textbook. - M.: RIOR, 2005. p. 315

[3] Official website of the Rating Agency "Expert". [Electronic resource] URL: http://www.raexpert.ru.

[4] G. Hogarth, J. Reidhill, P. Sinkler, Resolution of Banking Crises: Main Instruments and Costs//Banks: World Experience. 2009. No. 5. P. 4-9.

[5] Analysis of Commercial Bank Activities: Textbook for Bachelors and Masters/ed. by A. A. Kazimagomedova - Makhachkala: ALEF (IE Ovchinnikov), 2012. p. 228. 